\title{
ポリウレタンアミンから誘導される電解質 ポリマーの合成
}

\section{その凝集作用とその他の性質}

\author{
芹田 元・大谷規 隆・木村 誓 \\ 秋田大学鉱山学部然料化学科 (秋田市手形学園町 1-1)
}

\section{Preparation of Polymer Electrolytes Derived from Polyurethaneamine}

\author{
Their Flocculation Effects and Other Properties
}

\author{
Hajime Serita, Noritaka Ohtani, and Chikai Kimura \\ Department of Fuel Chemistry, Mining College, Akita University \\ (1-1, Gakuen-chō, Tegata, Akita)
}

\begin{abstract}
Polyurethaneamine (PUA) was prepared from $N$-methyldiethanolamine and hexamethylenediiso= cyanate. A variety of quaternary ammonium salts of PUA (cationic polymer) were prepared from PUA and alkyl bromides of various chain length $\left(\mathrm{C}_{2} \sim \mathrm{C}_{12}\right)$ with a view of obtaining good flocculants. In alkylating PUA with alkyl bromides, it was found that alkylation occured to urethane- $N$ as well as quaternization reaction, and using low molecule of urethane as model compound prepared from ethanol and hexamethylenediisocyanate, alkylation to urethane- $N$ was ascertained by the reaction of urethane and dodecyl bromide. The flocculation ability for aqueous suspension of kaoline was investigated in the relation to the structure of cationic polymers by measuring the sedimentation velocity, sedimentation volume, and turbidity. Cationic polymer obtained from PUA and the higher alkyl bromide showed good flocculation effect. The suitable range of degree of quaternization was 40 60\%. Cationic polymer was most effective for flocculation with increase of acidity. The most clarity of supernatant gave $40 \mathrm{ppm}$ turbidity at the dosage of $50 \mathrm{ppm}$ using cationic polymer (degree of quaternization $84.4 \%$ ) obtained from PUA and dodecyl bromide. Interraction (metachromasia) between methyl orange and cationic site of a number of cationic polymers were examined, and cationic polymers with the higher degree of quaternization derived from the higher alkyl bromides and PUA were shown large metachro= masia. Cationic polymers derived from the higher alkyl bromides showed good flocculating ability which are not inferior that of typical commercial products.
\end{abstract}

\section{1 緒 言}

著者ら汇数年来, 付加重合系のカチオン性高分子凝集 剂を合成し，それのカオリン懸濁液に対する凝集作用を 検討してきたが1) 3)，本報では $N$-(メチル)-ジエタノー ルアミン (MEA) とへキサメチレンジイソシアナート (HMDI) からポリウレタンアミンを合成し, それに構 造の異なった臭化アルキルを反応させ, 重付加系の新し いカチオン性高分子凝集㓮の合成を試みた。ポリウレタ ンアミンと臭化アルキルの反応において, 臭化アルキル は第四級化反応ばかりではなく, ウレタン $N$ ウのアル
キル化反応も起こっていることが認められ，モデル化合 物をエタノールと HMDI から低分子のウレタンを得, ウレタンと臭化アルキルの反応においてウレタン $N$ 称 もアルキル化していることを確認した。なお，カチオン 性高分子凝集郕としての性質をカオリン㲘濁液に対する 凝集効果について検討したので報告する。

\section{2 実験及び結果}

\section{$2 \cdot 1$ 試薬}

$N$-メチルジェタノールアミン (MEA) は市販品を水酸 化ナトリウムで処理した後, 減圧蒸留して $97 \sim 98^{\circ} \mathrm{C} / 8$ 
$\mathrm{mmHg}$ の留分を, ヘキサメチレンジイソシアナート (HMDI) は市販品をそのまま蒸留して $130 \sim 132^{\circ} \mathrm{C} / 14$ $\mathrm{mmHg}$ の留分を, ジメチルホルムアミド (DMF) はシ リカゲルで乾燥した後, トルエンジイソシアナートを少 量加えて減圧蒸留し $60^{\circ} \mathrm{C} / 35 \mathrm{mmHg}$ の留 分を, メタノ 一ル，エタノールは酸化カルシウムで乾燥した後蒸留し たものを使用した。その他, 触媒のジブチルチンジラウ ラート, 臭化エチル, 臭化ブチル, 臭化オクチル, 臭化 ドデシルは市販品をそのまま使用した。

\section{$2 \cdot 2$ ポリウレタンアミンの合成}

窒素導入管を備えた側管付き滴下漏斗，窒素排出管付 きコンデンサー, かくはん装置を備えた $500 \mathrm{ml}$ の三つ 口セパラブルフラスコを充分窒素置換した後 $23.8 \mathrm{~g}$ の MEA を入れ, 触媒としてジブチルチンジラウラートを $0.1 \mathrm{~g}$ 加え, 反応温度を $150^{\circ} \mathrm{C}$ に保ち, かくはんしなが ら $31.2 \mathrm{~g}$ の HMDI を $200 \mathrm{ml}$ の DMF に溶解したも のを約 $1 \mathrm{~h}$ 要して滴下し, 更に $5 \mathrm{~h}$ 反応を続けた。反応 終了後, ポリマーの DMF 溶液を約 10 倍量の酢酸エチ ルに加えて再沈して 減圧乾燥した。IR からウレタンの 特性吸収が， $3,300 \mathrm{~cm}^{-1}$ に NH 伸縮振動 ( $\mathrm{cm}^{-1}$ に $\nu_{\mathrm{C}}=\mathrm{O}$ が, $1,540 \mathrm{~cm}^{-1}$ に $\nu_{\mathrm{C}-\mathrm{N}}$ と $\mathrm{NH}$ 変角振動 （ס）の結合音が，1,260 $\mathrm{cm}^{-1}$ に $\nu_{\mathrm{C}-\mathrm{N}}$ に基づくと思わ れる吸収が現れていることからポリウレタンアミンの構 造を確認した。

\section{$2 \cdot 3$ 高分子疑集剂の合成}

\section{$2 \cdot 3 \cdot 1$ モデル化合物を用いた予備実験}

モデル化合物としてエタノールと HMDI からポリウ レタンアミン (PUA) の合成法に従って低分子のウレタ ン化合物を得た。IR では PUA の構造と同様なスペク トルを示した。得られたウレタンの約 $2 \mathrm{~g}$ を内容 $100 \mathrm{ml}$ のなす型フラスコにとり, $20 \mathrm{ml}$ の DMF に溶解し, 約 $7.2 \mathrm{~g}$ の臭化ドデシルを加え, $80^{\circ} \mathrm{C}$ で $16 \mathrm{~h}$ 反応を行っ

Table-1 Structure of urethane and $N$-dodecyl urethane.

\begin{tabular}{|c|c|c|}
\hline Structure & $\begin{array}{l}\text { NMR } \\
(\mathrm{ppm})\end{array}$ & $\operatorname{IR}\left(\mathrm{cm}^{-1}\right)$ \\
\hline I) & 110 & \\
\hline 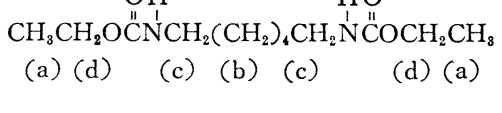 & $\begin{array}{ll}\text { b } & 1.22 \\
\text { c } & 3.04 \\
\text { d } & 3.96\end{array}$ & $\begin{array}{l}2920 \nu_{\mathrm{CH}} \\
1680 \nu_{\mathrm{C}=\mathrm{O}} \\
1530 \nu_{\mathrm{CN}}+\delta_{\mathrm{NH}} \\
1260 \nu_{\mathrm{CN}}\end{array}$ \\
\hline 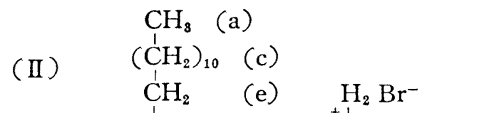 & $\begin{array}{ll}\text { a } & 0.92 \\
\text { b } & 1.14 \\
\text { c } & \end{array}$ & $\begin{array}{l}3300 \nu_{\mathrm{NH}} \\
2920 \nu_{\mathrm{CH}} \\
2780+\end{array}$ \\
\hline $\begin{array}{l}\mathrm{CH}_{3} \mathrm{CH}_{2} \mathrm{OCNCH}_{2}\left(\mathrm{CH}_{2}\right)_{4} \mathrm{CH}_{2}^{+1} \mathrm{NCOCH}_{2} \mathrm{C} \\
\begin{array}{lll}\text { (b) (g) } \mathrm{O}(\mathrm{f}) & \text { (d) (h) } \mathrm{O}(\mathrm{g})( \\
\text { or } & & \end{array}\end{array}$ & $\begin{array}{ll}\mathrm{c} & 1.22 \\
\mathrm{~d} & \end{array}$ & $2420 \mathrm{NH}_{2}$ \\
\hline $\begin{array}{cc}\mathrm{CH}_{3} & \text { (a) } \\
\left(\mathrm{CH}_{2}\right)_{10} & \text { (c) }\end{array}$ & $\begin{array}{ll}\text { e } & 3.58 \\
\mathrm{f} & 3.56 \\
\mathrm{~g} & 3.96\end{array}$ & $\begin{array}{l}1680 \nu_{\mathrm{C}=\mathrm{O}} \\
1620 \delta_{\mathrm{NH}} \stackrel{+}{\mathrm{N}} \mathrm{H}_{2}\end{array}$ \\
\hline 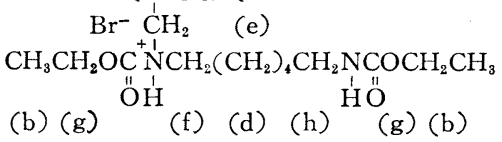 & h 3.04 & $\begin{array}{l}1530 \nu_{\mathrm{CN}}+\delta_{\mathrm{NH}} \\
1380 \stackrel{+}{\mathrm{N}} \mathrm{CH}_{2} \\
1260 \nu_{\mathrm{CN}}\end{array}$ \\
\hline
\end{tabular}

た。反応終了後, $\mathrm{DMF}$ 溶液を 約 10 倍量のエーテルに 加えて再沈し減圧乾燥を行った。この様にして得られた ウレタンと臭化ドデシルの反応生成物の構造を IR, NMR で調べた結果を Table-1 亿示した。

Table-1 から, モデル 実験で得られたウレタンの構 造は（I）に示す様な構造であることを IR 及び NMR の值から確認した。ウレタンと臭化ドデシルの反応生成 物は（II）又は（III）の構造が考えられるが 2,780, 2,420 そして $1,620 \mathrm{~cm}^{-1}$ の $\mathrm{NH}_{2}$ に基ゔく吸収スペク トルから構造 (III) よりは（II）が妥当と考えられる。 また，ウレタン（I）では $3,300 \mathrm{~cm}^{-1}$ の $\nu_{\mathrm{NH}}$ と 2,920 $\mathrm{cm}^{-1}$ の $\nu_{\mathrm{CH}}$ の面積強度は $\nu_{\mathrm{NH}}>\nu_{\mathrm{CH}}$ であり $1,530 \mathrm{~cm}^{-1}$ の $\nu_{\mathrm{CH}}+\delta_{\mathrm{NH}}$ と $1,450 \mathrm{~cm}^{-1}$ の $\delta_{\mathrm{CH}}$ を比較すると $\nu_{\mathrm{CN}}$ $+\delta_{\mathrm{NH}} \gg \delta_{\mathrm{CH}}$ であったがウレタンの $N$-アルキル化物に ついては $\nu_{\mathrm{NH}}<\nu_{\mathrm{CH}}$ そして $\nu_{\mathrm{CN}}+\delta_{\mathrm{NH}} \doteqdot \delta_{\mathrm{CH}}$ と変化し ており，NMR の結果をも考慮した結果，(II) と（III） の混合物と考えられる。N-ドデシルウレタンの一定量 を水溶解し, 遊離の臭素イオンを硝酸銀水溶液で滴定 した結果 $2.71 \times 10^{-3} \mathrm{eq} / \mathrm{g}$ の值を示し, 以上の結果に基 づき $N$-アルキル化の事実が確認された。

$2 \cdot 3 \cdot 2$ PUA とハロゲン化アルキルとの反応

供試 PUA と八ロゲン化アルキルの反応において第四 級化と同じくウレタンの $N$-アルキル化の起こる可能性 が考えられるので初めにモデル化合物につき，その模様 を確かめてから凝集剤の合成を試み， $N$-アルキル化の 分布を測定した。凝集剤の合成は，内容 $100 \mathrm{ml}$ のなす 型フラスコに約 $2.2 \mathrm{~g}$ の PUA をとり, $30 \mathrm{ml}$ の DMF に溶解し PUA の約 1.5 倍又は 2 倍モル量の臭化アル キルを加え, 窒素置換後密せんし, $80^{\circ} \mathrm{C}$ の温浴中で所 定時間反応を行った。反応終了後ポリマーの DMF 溶液 を約 10 倍量のエーテルに加えて再沈して減圧乾燥を行 った。第四級化の割合，N-アルキル化の 割合は柳本電 位差滴定装置を用いて，遊離の系素イオンを硝 酸銀溶液で滴定すること，及び末反応のアミノ 基を過塩素酸で電位差滴定することにより決定 した。各種ハロゲン化アルキルと PUA から得 られた各種凝集剤を Table-2 に示した。 臭化エチル，臭化ブチル，臭化オクチル，臭 化ドデシルと PUA と反応して得られた第四級 化ポリマーを，それぞれ $\mathrm{C}_{2}, \mathrm{C}_{4}, \mathrm{C}_{8}, \mathrm{C}_{12}$ と以 下略称する。

\section{$2 \cdot 4$ 疑集試験}

$2 \cdot 4 \cdot 1$ 供試カオリン

凝集剤としての性能試験に用いたカオリン （和光純薬 (株) 製) 325 mesh 以下に粉砕 して $105 \sim 110^{\circ} \mathrm{C} て ゙ ~ 24 \mathrm{~h}$ 乾燥したものを使用 した。粒度分布を調べるためにコールターカウ ンター（日科機（株）製）で測定した粒度分布 
Table-2 Polymer electrolytes derived from polyurethaneamine and various alkyl bromides.

\begin{tabular}{|c|c|c|c|c|c|c|c|c|c|}
\hline \multirow{2}{*}{$\begin{array}{l}\text { Exp. } \\
\text { No. }\end{array}$} & \multirow{2}{*}{$\begin{array}{c}\mathrm{PUA}^{1)} \\
(\mathrm{g})\end{array}$} & \multicolumn{2}{|c|}{ Alkylbromides } & \multirow{2}{*}{$\begin{array}{l}\mathrm{DMF} \\
(\mathrm{ml}) \\
\end{array}$} & \multirow{2}{*}{$\begin{array}{c}\text { Temp. } \\
\left({ }^{\circ} \mathrm{C}\right)\end{array}$} & \multirow{2}{*}{$\begin{array}{c}\text { Time } \\
\mathrm{d} \\
(\mathrm{h})\end{array}$} & \multirow{2}{*}{$\begin{array}{l}\text { Yield } \\
(\mathrm{g})\end{array}$} & \multicolumn{2}{|c|}{ Degree of $N$-alkylation } \\
\hline & & Name & $(\mathrm{g})$ & & & & & Amine $\mathrm{N}$ & $\begin{array}{c}\text { Urethane N } \\
(\%)\end{array}$ \\
\hline $\mathrm{C}_{2}-1$ & 2.16 & Ethyl bromide & 1.79 & 30 & 80 & (1) & 2.5 & 46.8 & 6.70 \\
\hline $\mathrm{C}_{2}-2$ & 2.16 & Ethyl bromide & 1.79 & 30 & 80 & (2) & 2.9 & 53.5 & 9.65 \\
\hline $\mathrm{C}_{2}-3$ & 2.16 & Ethyl bromide & 1.79 & 30 & 80 & (4) & 3.2 & 81.6 & 10.1 \\
\hline $\mathrm{C}_{2}-4$ & 2.16 & Ethyl bromide & 1.79 & 30 & 80 & (6) & 3.4 & 88.3 & 18.2 \\
\hline $\mathrm{C}_{2}-5$ & 2.16 & Ethyl bromide & 1.79 & 30 & 80 & 23 & 3.7 & 95.8 & 45.1 \\
\hline $\mathrm{C}_{4}-1$ & 2.16 & Butyl bromide & 2.16 & 30 & 80 & (4) & 2.6 & 52.6 & 6.30 \\
\hline $\mathrm{C}_{4}-2$ & 2.16 & Butyl bromide & 2.06 & 30 & 80 & (8) & 3.4 & 56.5 & 22.9 \\
\hline $\mathrm{C}_{4}-3$ & 2.16 & Butyl bromide & 2.06 & 30 & 80 & 8 & 3.5 & 79.4 & 27.7 \\
\hline $\mathrm{C}_{4}-4$ & 2.16 & Butyl bromide & 2.06 & 30 & 80 & 13 & 3.8 & 89.4 & 37.2 \\
\hline $\mathrm{C}_{8}-1$ & 2.16 & Octyl bromide & 2.90 & 30 & 80 & 7 & 3.3 & 68.4 & 24.2 \\
\hline $\mathrm{C}_{8}-2$ & 2.16 & Octyl bromide & 2.90 & 30 & 80 & 11 & 3.5 & 75.4 & 38.6 \\
\hline $\mathrm{C}_{8}-3$ & 2.16 & Octyl bromide & 2.90 & 30 & 80 & 18 & 3.5 & 81.5 & 40.3 \\
\hline $\mathrm{C}_{8}-4$ & 2.16 & Octyl bromide & 2.90 & 30 & 80 & 24 & 3.5 & 86.6 & 43.1 \\
\hline $\mathrm{C}_{12}-1$ & 2.16 & Dodecyl bromide & 2.90 & 30 & 80 & 6 & 3.0 & 38.2 & 7.72 \\
\hline $\mathrm{C}_{12}-2$ & 2.16 & Dodecyl bromide & 2.90 & 30 & 80 & 10 & 3.8 & 48.2 & 33.2 \\
\hline $\mathrm{C}_{12}-3$ & 2.16 & Dodecyl bromide & 2.90 & 30 & 80 & 13 & 3.6 & 59.5 & 53.1 \\
\hline $\mathrm{C}_{12}-4$ & 2.16 & Dodecyl bromide & 2.90 & 30 & 80 & 18 & 3.9 & 84.4 & 59.4 \\
\hline
\end{tabular}

1) PAU Polyurethaneamine

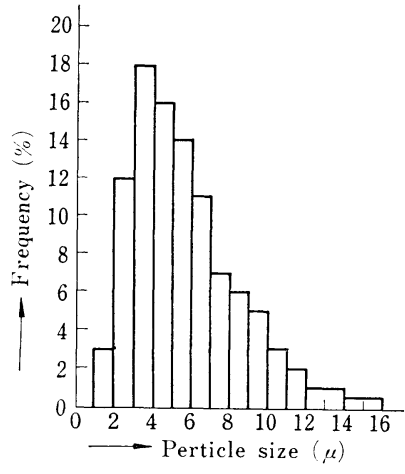

Fig.-1 Particle size distribution of kaolin.

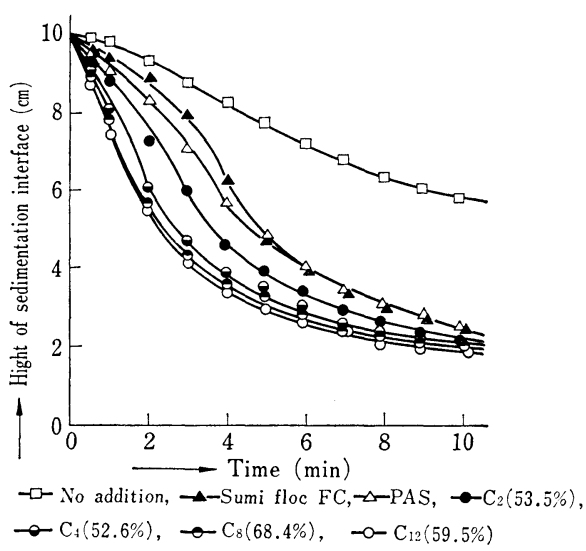

Fig.-2 Sedimentation curve of typical flocculants (5\% kaolin suspension, pH 5.2, flocculant dosage $30 \mathrm{ppm}$ )
は Fig.-1 に示した。

$2 \cdot 4 \cdot 2$ 沈降速度

内径 $10 \mathrm{~mm}$, 長さ $25 \mathrm{~cm}$ の共せん目盛付き沈降管に $0.50 \mathrm{~g}$ のカオリンと一定濃度の凝集剂水溶液を添加して $10 \mathrm{ml}$ とした。その後, $1 \mathrm{~min}$ 上下に激しく振り動かし た後,直ちに沈降管を垂直に静置し,現れてきた沈降界面 の移動を示す目盛を一定時間ごとに読んでプロットし， 沈降曲線を作成した。この時の初期の等速沈降部分の速 度をもって沈降速度とし，単位を $\mathrm{cm} / \mathrm{min}$ で表した。

PUA の第四級塩 $\left(\mathrm{C}_{2}, \mathrm{C}_{4}, \mathrm{C}_{8}, \mathrm{C}_{12}\right)$ 及び市販凝集剤に よるカオリン睬濁液の沈降の一般的様相を示すと Fig.2 の様な挙動を示した。

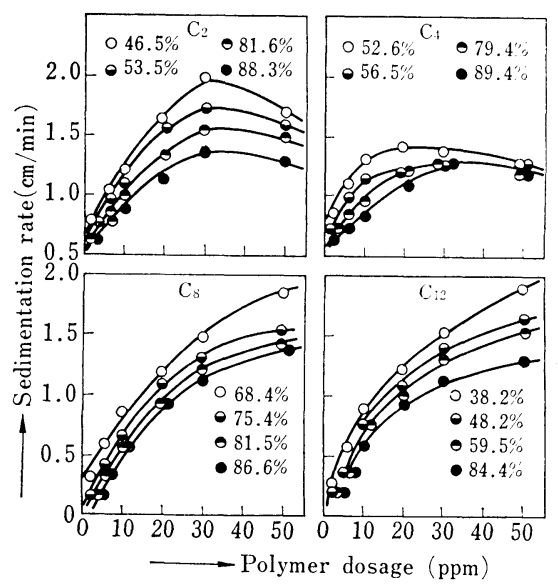

Fig.-3 Relation between sedimentation rate and the amount of polymer electrolytes added to $5 \%$ kaolin suspension ( $\mathrm{pH} \mathrm{5.2)}$ 
また，沈降速度の測定において，凝集凨を添加して一 定時間上下に激しく振り動かした後, 静置して, わずか $10 \mathrm{~s}$ 以内にフロックの形成が認められ，それが集合し てアグリゲートを形成して短時間に沈降していくのが観 察された。この様にして得られた結果を Fig.-3 に示し た。

\section{$2 \cdot 4 \cdot 3$ 沈降容積}

沈降速度を測定した後も沈降管を静置して $24 \mathrm{~h}$ 経過 した後における沈降容積を測定して単位 $\mathrm{ml}$ で表示し た。 $24 \mathrm{~h}$ 経過した後の容積を平衡值とみなし沈降容積と し, 得られた值を Fig.-4 に示した。

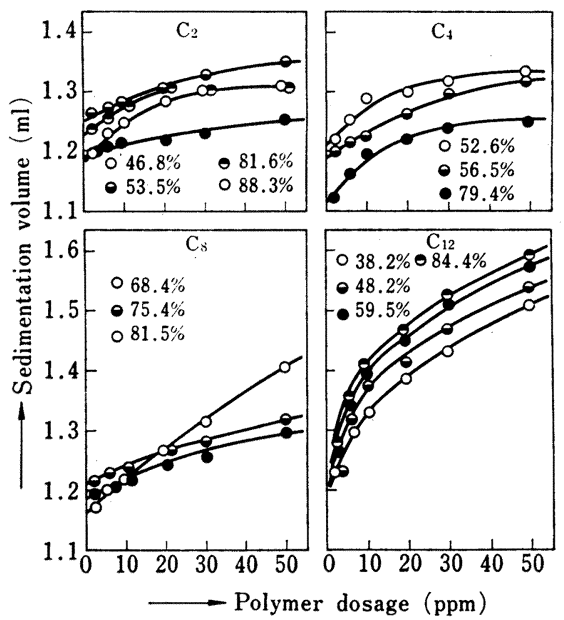

Fig.-4 Relation between sedimentation volume and the amount of polymer electrolytes added to $5 \%$ kaolin suspension ( $\mathrm{pH} \mathrm{5.2).}$

\section{$2 \cdot 4 \cdot 4$ 濁度}

沈降速度の測定と同様な操作を行い, 沈降管を静置し てから $10 \mathrm{~min}$ 後に管の上澄み液中央部から試料を $3 \mathrm{ml}$

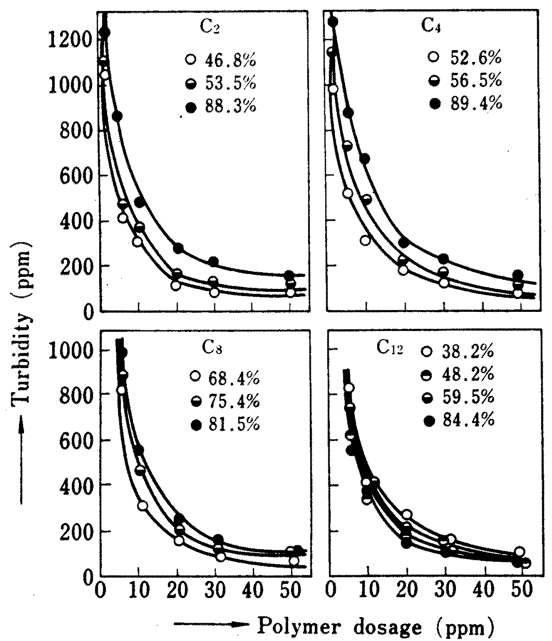

Fig.-5 Relation between turbidity and amount of polymer electrolytes added ( $\mathrm{pH} \mathrm{5.2)}$. 採取し，その濁度（ppm）を日本精密光学（株）製濁度 計 SEP-PT-201 により測定し清澄性の尺度とした。清 澄性の基準として上澄み液の残留濁度を高分子凝集剂の 添加量に対して図示すると Fig.-5 の様になった。

\section{$2.5 \mathrm{pH}$ の影䈏}

臭化エチルを第四級化郕として用いて得られた高分子 凝集剂 $\mathrm{C}_{2}$ (第四級化率：68.4\%）を用い，50 ppm の添 加量で酸性側を塩酸で, 塩基性側を水酸化ナトリウムを 用いて $\mathrm{pH}$ の調整した $5 \%$ カオリン䅗濁液に対する沈 降速度と清澄性を測定した結果を Fig.-6 に示した。

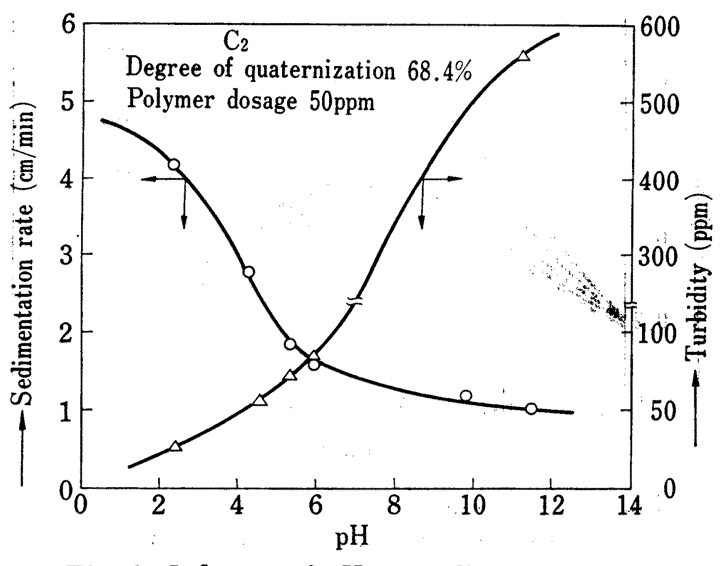

Fig.-6 Influence of $\mathrm{pH}$ on sedimentation rate or turbidity in 5\% kaolin suspension.

\section{6 市販疑集剂の性能}

本研究において得られた PUA の第四級塩を具体的に 評価する資料として市販の凝集剤 5 種類, PAS, Sumi Floc FC, Himoloc Neo 600, Uniflocer UF 101, 硫酸

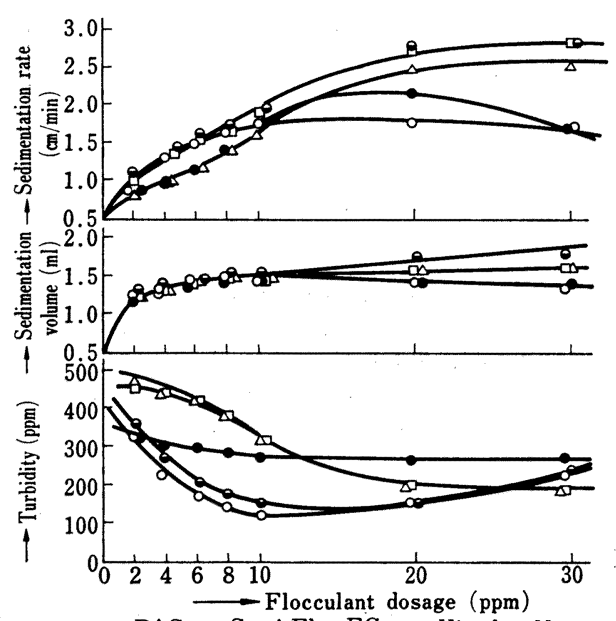
$\infty$ PAS, $\square$-Sumi Floc FC, $\lesssim$ Himoloc Neo 600, $\rightarrow$ Uniflocer UF 101, $\rightarrow$ Aluminium Sulfate

Fig.-7 Sedimentation rate, sedimentation volume and turbidity of various commercial flocculants to $5 \%$ kaolin suspension $(\mathrm{pH}$ 4.6). 
アルミニウムについて凝集効果を沈降速度, 沈降容積, そして濁度について測定した結果を Fig.-7 に示した。

\subsection{PUA の第四級塩によるメチルオレンジの 取り} 込み

各種 PUA の第四級塩の $160 \times 10^{-5} \mathrm{M}$ 水溶液とメチ ルオレンジの $3.76 \times 10^{-5} \mathrm{M}$ との 1 対 1 の吸光曲線につ いては Fig.-8 に示し, 第四級化の割合の異なる $\mathrm{C}_{12}$ に ついては上と同様な濃度でメチルオレンジとの 1 対 1 溶 液についての吸光度曲線を Fig. -9 に示した。

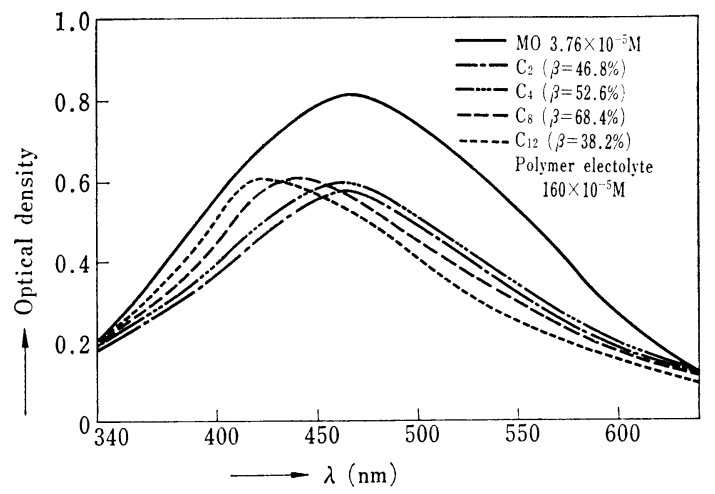

Fig.-8 Absorption spectra of methyl orange in the presence of polymer electrolyte $(\mathrm{Me}=$ thyl Orange/polymer electrolyte $1 / 1 \mathrm{vol} /$ vol, $\mathrm{pH} 5.2,1 \mathrm{~cm}$ cell).

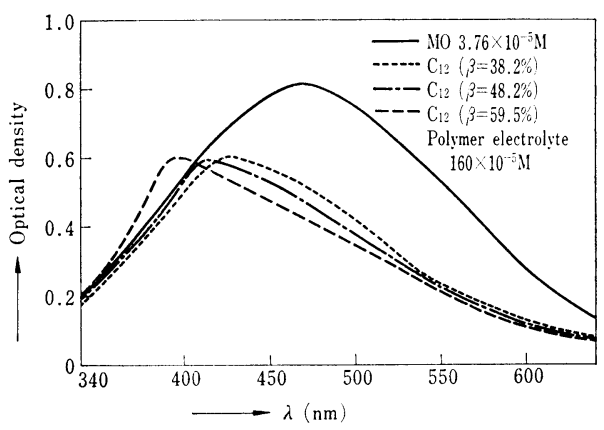

Fig.-9 Absorption spectra of methyl orange in the presence of polymer electrolyte con= taining different degree of quaternization (Methyl Orange/poymer electrolyte $1 / 1$, $\mathrm{vol} / \mathrm{vol}, \mathrm{pH} 5.2,1 \mathrm{~cm}$ cell).

\section{3 考察}

\section{$3 \cdot 1$ 沈降速度}

凝集剤の無添加の場合はゆるやかにほぼ直線的に沈降 しており，PUA の第四級塩を添加した場合は $\mathrm{C}_{2}$ を除 いて最初から凝集が起こり，その後は徐々に沈降してい るのが Fig.-2 から明らかである。又, $\mathrm{C}_{2}$ 及び市販凝 集剤である Sumi Floc FC, PAS の場合はいずれも誘導 期を持っており, 約 $2 \sim 3 \mathrm{~min}$ 経過した後急速に沈降が
起こり，更に徐々に沈降していることが観察された。 PUA 第四級塩を用いたカオリン䀣濁液の凝集において, 初めに急激にフロックを形成し, 凝集し, 沈降してくる のが特徴と考えられる。この様に PUA の第四級塩が高 分子凝集剂としてすぐれた効果のあることを直観的に知 ることができる。凝集剤添加後 $10 \mathrm{~min}$ 経過した所でほ ぼ沈降平衡に達している。Fig.-3 に示している様に第 四級化に用いる臭化アルキルのアルキル鎖長の長いもの ほど沈降速度は大きく，又，多少例外はあるが，第四級 化率に関してては，ほぼ 40〜60\% のものが良好であるこ とが認められた。比較的アルキル鎖長の短い臭化エチ ル，臭化ブチルを第四級化䒽として用いて得られた高分 子凝集剤では添加量が $30 \mathrm{ppm}$ の所に最大值 $1.3 \sim 2.0$ $\mathrm{cm} / \mathrm{min}, 1.3 \sim 1.4 \mathrm{~cm} / \mathrm{min}$ を有し, 最適添加量の存在が 認められた。一方，臭化オクチル，臭化ドデシルを第四 級化剂として用い得られた高分子凝集剤はいずれも添加 量の増加に伴って沈降速度は増加していることが観察さ れた。

\section{2 沈降容積}

Fig.-4 に示している様に臭化エチル，臭化ブチル， 臭化オクチル，臭化ドデシルを第四級化剂として用いて 得られた高分子凝集剂に関しては，多少の例外はある が，沈降速度とほぼ同様な傾向を示し，いずれも第四級 化の割合が 40〜60\% のものが大きな值を示している。 第四級化の割合が大きいものほど, 多くのカオリン粒子 を静電的に吸着し, 沈降した後, 圧縮され容積は小さく なるものと考えられる4),5)。一方, $\mathrm{C}_{12}$ は他の 3 種の凝 集剤とは異なった挙動が観察されたが，これは臭化ドデ シルが第四級化剤として導入されることにより，前の 3 種の凝集剤よりも踈水基であるアルキル鎖長が大であ り，アルキル基の炭素数が増加するにつれて脱水，凝集 が容易になるものと考えられる

\section{3 濁 度}

$\mathrm{C}_{2}, \mathrm{C}_{4}, \mathrm{C}_{8}, \mathrm{C}_{12}$ のいずれの高分子凝集剤においても， その添加量の増加に伴って良好な清澄性を示しているこ とは Fig.-5 からも認められる。 $\mathrm{C}_{2}, \mathrm{C}_{4}, \mathrm{C}_{8}$ に関しては 第四級化の割合が小さくなるにつれて清澄性は増加し, また, $50 \mathrm{ppm}$ の添加量の所で最も清澄性は良く, それぞ れ 105〜 190, 95〜185 そして 70〜158 ppm の值を示し ている。一方, $\mathrm{C}_{12}$ については $\mathrm{C}_{2}, \mathrm{C}_{4}, \mathrm{C}_{8}$ とは異なり, 第四級化の割合が大きいものほど良好な清澄性を示し， $50 \mathrm{ppm}$ の添加量の時 40 148 ppm の值を示し, 得られ た高分子凝集剤の中では最も良好な清澄性を示した。

\section{$3.4 \mathrm{pH}$ の影響}

沈降速度は酸性の度合いが強いほど大きく, 中性付近 にかけて急激な減少を示し，更に塩基性側にかけては， わずかながら減少し， $\mathrm{pH}$ の值が 10 以上になるとほと んど平衡に達し, その值は $1 \mathrm{~cm} / \mathrm{min}$ を示した。濁度に 
ついても沈降速度と同様な傾向を示し，塩基性側から酸 性側沉仃急激に清澄性は上昇し, 得られた凝集剤の 中で最も凝集効果の小さい $\mathrm{C}_{2}$ でさえも $\mathrm{pH}$ の值が 3 付 近で濁度の值が $25 \mathrm{ppm}$ を示した。カオリンが水中に䀣 濁している場合, 粒子の表面は負に帯電しているといわ れており，酸性側で非常に良好な凝集効果を示したが， これはカオリンの構造が板状結晶でその端に存在するア ルミナは水素イオンと結合して見掛け上正の荷電を有し ていると考えられている ${ }^{6)}$ 。板状結晶の面は負の荷電を 帯び、端は正電荷を带びて面と端が結合してある程度凝 集してくるものと考えられている7”。一方，PUA の未 反応部分洼アンモニウム塩となり，第四級化している部 分と共にカオリンの板状結晶の酒に静電的仅着して凝 集せしめるものと考えられる。

\section{5 市販凝集剤の性能}

Fig.-7 を Fig.-3 Fig.-5 と比較すると沈降速度, 沈降容積のいずれも Uniflocer UF 101, Sumi Floc FC, Himoloc Neo 600 の方がすぐれており, 次に硫酸アル ミニウム, PAS の順であった。沈降速度, 沈降容積及 び濁度の間には必ずしも相関性は認められなかった。清 澄性に関しては, PAS, Uniflocer UF 101 が使用した 市販凝集郕の中では最も良く, 添加量 $10 \mathrm{ppm}$ の所に最 小值を有して抢り，それぞれ $130,154 \mathrm{ppm}$ の濁度を示 した。その他, Sumi Floc FC 及び Himoloc Neo 600 は添加量の増加につれて清澄性は増加するが添加量が $20 \mathrm{ppm}$ 以上になると, ほとんど平衡に達しその值は $200 \mathrm{ppm}$ を示した。一方, 硫酸アルミニウムの場合は添 加量を増しても顕著な変化は認められず $30 \mathrm{ppm}$ の添加 量の時 $300 \mathrm{ppm}$ の值を示した。他方, PUA の第四級 塩では再分散の現象は認められず， $\mathrm{C}_{12}$ を用いた場合最 も良好な清澄性を与え, 添加量 $50 \mathrm{ppm}$ の時の濁度は $40 \mathrm{ppm}$ を示した。沈降速度では市販凝集剤が良好で, 清澄性に関しては PUA の第四級塩が良好な結果を示し た。以上今回合成した PUA の第四級塩は代表的な市販 凝集剤と比較してそん色のない性能を有することを知る ことができた。

\subsection{PUA の第四級塩によるメチルオレンジの取り 込み}

臭化エチル，臭化ブチルを第四級化剂として用いて得 られた PUA の第四級塩では Fig.-8 に示す様にメチル オレンジ（MO）の吸収スペクトルと全く同様であった が，臭化オクチル，臭化ドデシルを第四級化㨈として用 いて得られた PUA の第四級塩では MO の $462 \mathrm{~nm} の$ 吸収が $440 \mathrm{~nm}$ あるいは $420 \mathrm{~nm}$ に新しく $\lambda_{\max }$ を持つ 吸収帯 (メタクロマジー帯) が観察された ${ }^{8) \sim 10) 。 又, ~}$ $\mathrm{C}_{12}$ を用いて第四級化の割合を $38.2 \%, 48.2 \%, 59.5 \%$ と変化させた場合については Fig.-9 に示している様に 第四級化の割合が増加するにつれて，より短波長側に新 しい吸収帯を示した。これは高分子電解質の site 上に静 電的に引き寄せられた色素が会合するためと考えられて いる。又, 凝集作用についても第四級化の割合が増加す ることにより疎水基の占める割合も増加し, 従って脱水 が容易になりやすく，荷電の中和と共に粒子の疎水性を 増大させることにより凝集効果が増加するものと考えら れる(4),5)。それゆえ, PUA の第四級塩に関しては MO の取り込みによるメタクロマジーの度合いが凝集効果を 決定する場合, 何らかの関連性を暗示しているものでは なかららかと考兄られる。（昭和 54 年 4 月 4 日受理）

\section{文献}

1）芹田 元，木村 誓，村井幸一，高橋幸男，高分子諭文 集, 33, 351 (1976)

2）木村 整, 芹田 元, 村井幸一, 高橋幸男, 油化学, 25, 424 (1976)

3）芹田 元，大谷規隆，木村 誓，用水々廃水， 19, 755 (1977)

4) 松本恒隆, 化学, 30, 515 (1975)

5）大森英三，“高分子㠜集剤” 高分子刊行会 (1973) p. 35

6) R.K. Schofield, H.R. Samson, Discussions Faraday Soc., 18, 135 (1954)

7) N. Street, J. Colloid Sci., 12, 1 (1957)

8) L. Michaels, J. Phys. \& Colloid Chem., 54, 1 (1950)

9) M. Schubert, A. Levine, J. Am. Chem. Soc., 17, 4197 (1955)

10) M. Schubert, M.K. Pal J. Phys. Chem., 67, 1821 (1963) 